1) 18 th Biennial Report: Chem. Eng., 15, No. 12, 137 (1958)

2) J. A. Vaccari : Materials Design Eng, 63, No. 5,78 (1966)

3) G.W. Cunningham: Corrosion, 12, $389 \mathrm{t}$ (1956)

1) 中讯，栄，原田：火力発電，14，No.6，34 (1963)

5) W. D. Nils, H. R. Sanders: Trans. ASME, 84, Series A, 178 (1962) p. 178 186

6) L. A. Exley, A. E. Tamburrino, A. J. O'neal: Power, 110, No. 4, 69 (1966)

7) L. K. Pendle, R. D. Wilson: J. Inst. Fuel, 29, No. 9, 372 (1956)

8) P. Muller: Chem.Ing. Techt, 31, Nr. 1, 345 (1959)

9) A.P.I.Co.: Recommendation paper

10) G. Whittingbam: Trass. Faraday Soc, 44, 141 (1948)

11) W.F. Harlow: P. I. M. E, 169, 359 (1949)

12) H. Karlsson: Bureaw of Mines Report of Investigation (1953)

13) G. G. Thurlow, M. S. Graduate: P. I. M. E., 189, No. 20.
571 (1954)

14）有田，尾形，松田：火力発西，17, No.4, 9 (1966)

15）中沢：火力替電，17，No.7，22 (1965)

16) W. Nelson, C. Cain: Trans. ASME, 82, Series A, 194 (1960)

17) W. Nelson, C. Cain: Trans. ASME, 83, Series A, 468 (1961)

18) C. L. Mount, G.C. Wiedersun: Trans. ASME, 87, Series A, 250 (1965)

19) W. Nelson: J. Inst. of Fuel, 38, No. 291, 179 (1965)

20) K. Wickert: $B W K, 16, \mathrm{Nr} .2,67$ (1964)

21) A.D. Foster: Trans. ASME, B1, Series A, 234 (1959)

22) F. Umland: Werks. Korr, 16, Nr.10, 871 (1965) p. 871 875

23) G. J. Ryan, N.E. Ryan: Australasian Corr. Eng., B, No. 2, 27 (1965)

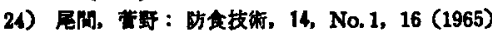

25) W. Grim: Combustion, 34, No.9, 38 (1963)

高張力鋼の硫化物腐食割れについで

渡辺正紀**向井喜楌**

棈音

近時，高張力銿の目さましい進出により，石油精製萃 直閔係にも盛んに使用されるよ タンクが硫化物腐食割れを起こすとい5束故”があいつ ぎこの問題に対する关心が高くなった。

本䄸俚特に問題の多い高張力鉷溶接部の硫化物席食割 れに対する諸特性について，主として簕者らが行なった 試倹結果を中心にをとめたすのであり，更に最近䇺者ら

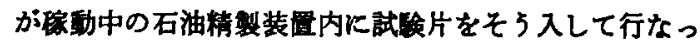
たフラントテスト2) の結果をる含めたすのである。

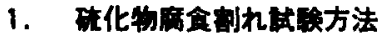

本稿で述べる実敛室加速試匰は次に述へる万法によ。 た。

すなわち，图1に示すような機粗の引㲀り定荷重方式

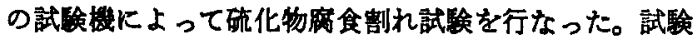
摤の外睍を图 2 に示す。

属食液は别に設けた腐食液調整槽で，0.5\% 酢酸水溶 液に $35^{\circ} \mathrm{C}$ て $\mathrm{H}_{2} \mathrm{~S}$ を飽和させたるのである。この腐食液 を調整橧から取り出して硫化物腐食割れ試験機の腐食槽 に注入し24時間ことに新しい液と取りかえた。

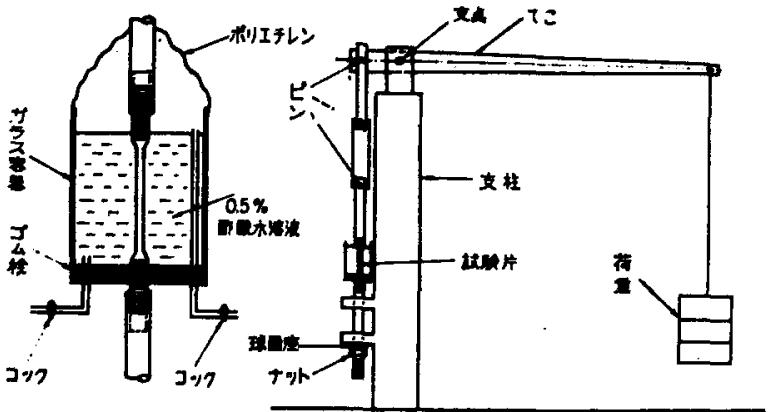

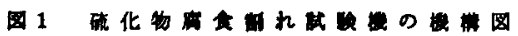

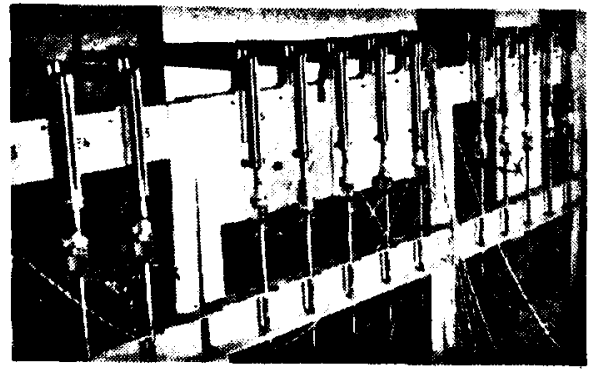

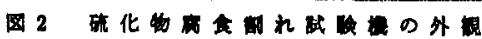

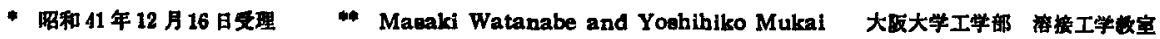


試鏂は試験機の荷重を別に用意した荷重検定器で検定

して後，試験片を取りつけ腐食液を注入すると同時に荷 重をかけた。

荷重の付加時より試験片が破断するまでの時間る゙タイ マーにより測定して破断居間とした。

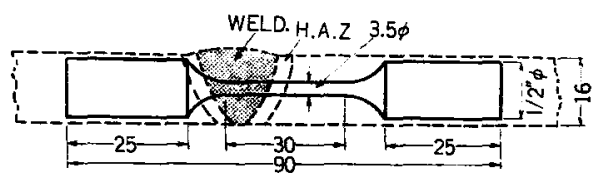

(a) 手整挃
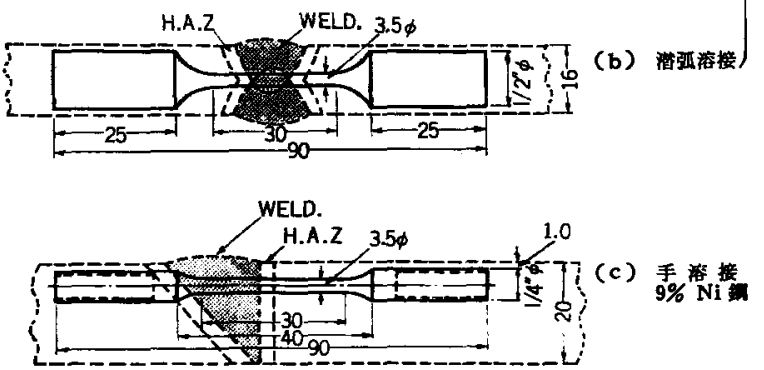

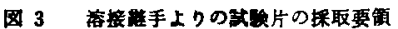

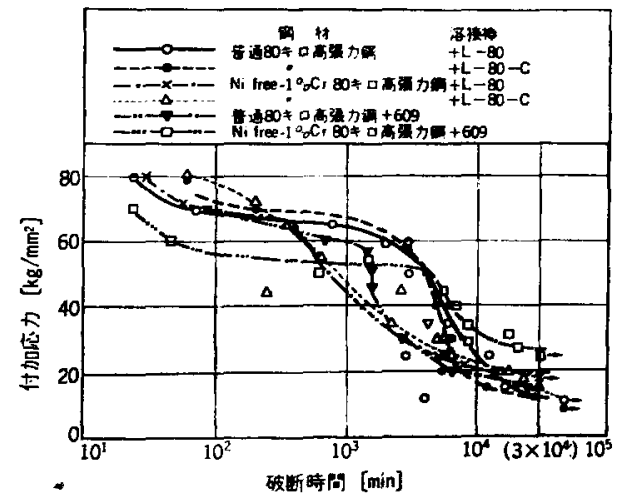

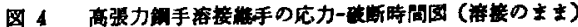

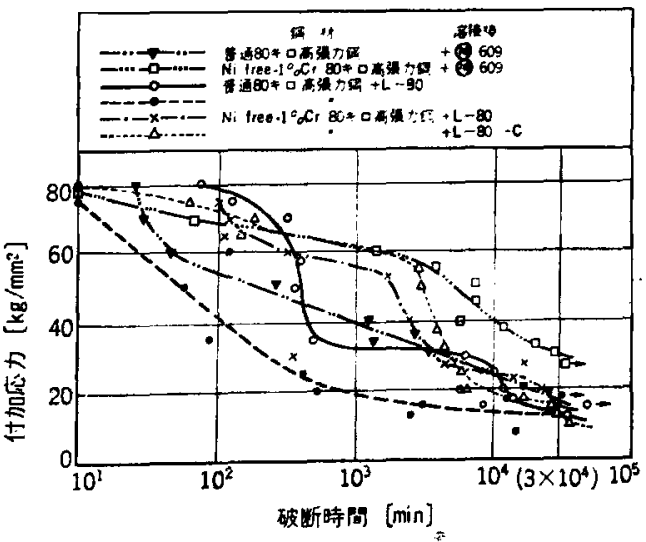

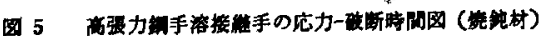

\section{2. 各種高張力鋼溶接㮉手の限界応力值}

各種現用高張力鋼および 9\% Ni 鋼の溶接継手より図 $3^{22}$ に示す要領で丸柈平滑継手引張り試験片を採取し，硫 化物腐食割机試験を行ない応力一破断時間曲線を求めた。

その結果を図 4，5，6 $6^{23} ， 7^{32}$ 亿示す。

図 4 仕普通 $80 \neq$ 中高張力鋼および耐硫化物 简食割九高張力鋼之して筆者の一人（渡辺）か 提唱した Ni free- $1 \% \mathrm{Cr} 80$ キロ高張力鋼の手 溶接継手の溶接のままでの結果である。また図 5 はこれらを応力焼鈍 $\left(600^{\circ} \mathrm{C}, 30\right.$ 分，空冷） した場合の結果である。

両因を見ると，応力の比校的高い所ではそれ ぞれの継手でかなり寿命が異なるようである。 しかし，限界値付近の応力になるといずれす差 が比較的少なくなっているようである。

図 6 は $\mathrm{Ni}$ free- $1 \% \mathrm{Cr} 80$ キ口高張力鋼の潜 弧溶接継手の溶接のままの結果であるが，破断 位膡がすへて熱影㨽部であったためか，心線が 変わっても汪とんど差異がない。

図 $7^{33}$ は 9\% Ni 鋼の溶接継手の溶接のままでの結果で あるが，この場合は溶接棒の種類により硫化物腐食割れ 感受性がかなり異なることがよくうかがえる。すなか ら，溶接棒としては $10 \% \mathrm{Ni}$ 棒（共金）を用いた場合が 最もよく，16\% Cr-39\% Ni 棒を用いた場合がこれに次

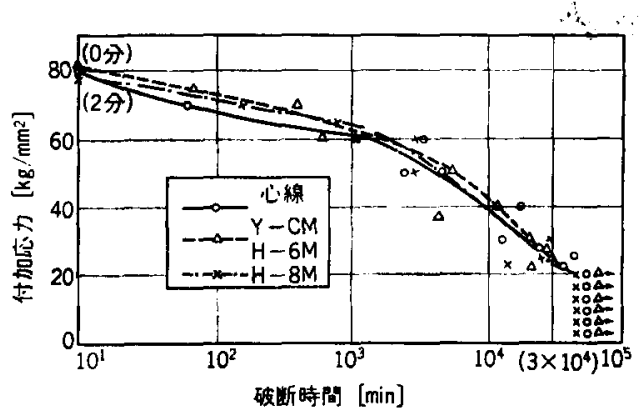

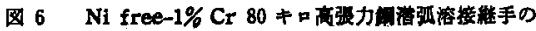

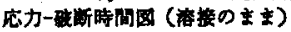

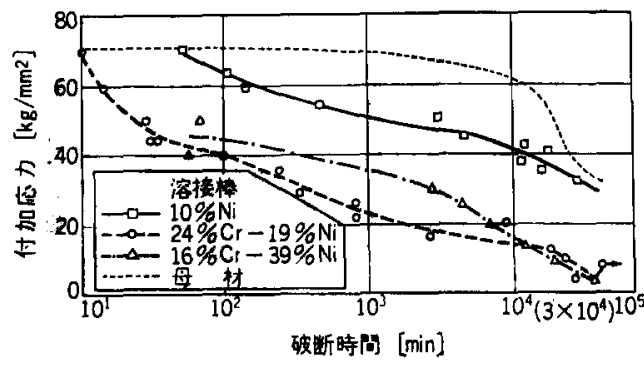

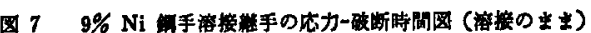


き， $24 \% \mathrm{Cr}-21 \% \mathrm{Ni}$ 棒を用いた場合が最も悪い。

$9 \% \mathrm{Ni}$ 鋼の場合の共金以外の溶着金属の場合には，腐 食液中で母材との間にかなりの電位差を生ずるるのと考 えられ，この電位差により電気化学的に虔食が促進され る効果があり，その結果割れやすくしたすのと考えられ る。

図 84には，これらの溶接材ちよびその他の各種現用 高張力鋼の溶接継手の限界応力值を示した。なお，本稿

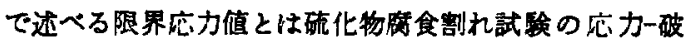
断時間曲線が $3 \times 10^{4}$ 分（約 20 日）を通る点の応力值の ことである。

図8で高張力鋼の級が高くなるはど，堸材自身の限界 庒力值は低下する。溶接継手についてす同椂の傾向が認 められ、しかる，どの釉の高張力銅であ容婪継手の限界 応力值が母材のそれよりかなり低い值を示している。

Ni free-1\% Cr 80 キロ高唇力銅でる溶接継手になる とその限界度力值は普通の 80 キ口高張力銅の母材のそ れと同程度か，それ以下に低下していることがわかる。 Ni free-1\% Cr 80 キ口高長力銅の潜弧溶接継手の限界 応力值は手溶接の場合よりかなり高い值を示している

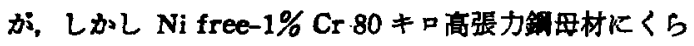
でるとやはり低い値を示している。ここで注目すべさ

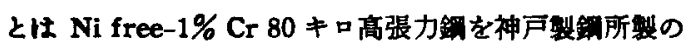
酎硫化物属食割れ用溶棒 609 で手溶接したるのの限界 応力值か比校的高い值を示していることである。これを 赎釚したものはさらによくなっている。

9\% Ni 鈵手溶接継手の場合，溶接棒が共金である場合 にくらイ，異䡚金属の场合にはその限界応力値がかなり 低い值を示している。この原因として異種溶着金屈（母

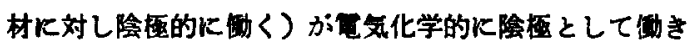
度食を促進させたことす一因と考えられる。

图8で各銅種の溶接継手を応力绕釚した场合の組織的 な面からの限界応力の变化を見るとはとんどの銅梳で 钝により限界応力値は中や低下している。たた $9 \% \mathrm{Ni}$ を $24 \mathrm{Cr}-19 \mathrm{Ni}$ で溶努したるのは $600^{\circ} \mathrm{C}$ の残鈍て限界応
力值がきわめて高くなっていることは興味深い。9\% N 銅の conventional $\mathrm{Ac}_{1}$ 変態点は $640^{\circ} \mathrm{C}$ 付近で (tru $\mathrm{Ac}_{1}$ は約 $580^{\circ} \mathrm{C}$ ) あるので $600^{\circ} \mathrm{C}$ の等鈍温度が $\mathrm{Ac}_{1}$ 品 にきわめて近かったことによるすので，この点につい は後述する。

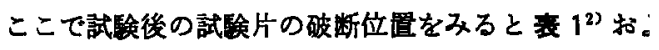
び表 $2^{33}$ のうである。表 1 は 80 キ口高張力鋼の場合。 破断位圊であるが，この表をみると手溶接試験片では〉 いたいにおいて溶接ボンド部付近で破断しているものる 多い。一方潜弧溶接試験片ではほとんどのすのが熱影 部の母材よりで破断していた。

ナなわち，80キロ高張力銅の場合，手溶接継手では才 ンド部付近が取も弱く，潜弧溶接継手では熱影警部の曰 材よりが最す弱い。しかも図8で明らかなよ5に，潜引 溶椄手の限界応力值より手溶継手の限界応力値のフ がはるか低い。上上のことから手溶接継手のボンド咅 はきわめて劣化していると侾えられる。

表 2 は $9 \% \mathrm{Ni}$ 銅手溶接継手の破断位置を示したすの であるが、10\% Ni 棒 (共金)で容接したすのでは溶着 金属部で破断したものがきわめて多い。しかし，一方2 Cr-21 Ni 棒で容接したるのでは付加応力が $40 \mathrm{~kg} / \mathrm{mm}$ 以上の場合には，すへて溶接ボンド部で破断しており， それ以下の応力で性とんどすべて熱影签部のなか忹と で破断している。さらに $16 \mathrm{Cr}-39 \mathrm{Ni}$ 棒で溶妾したもの では付加応力が $25 \mathrm{~kg} / \mathrm{mm}^{2}$ 以上の坦合には，すへて深 接ボンド部で破断してお゙り，それ以下の応力值の場合い は熱影部のなかどで破断している。

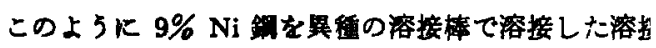

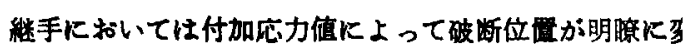
化するといらきわめて興味深い結果が得られた。

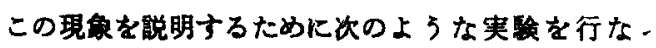
た。なから，9\% Ni 銅を $1,250^{\circ} \mathrm{C}$ および $850^{\circ} \mathrm{C} の$ 温度でそれぞれ1時間加熱し，水命したいのの応力ー破

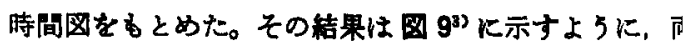
曲線が $35 \mathrm{~kg} / \mathrm{mm}^{2}$ の点で交差している。

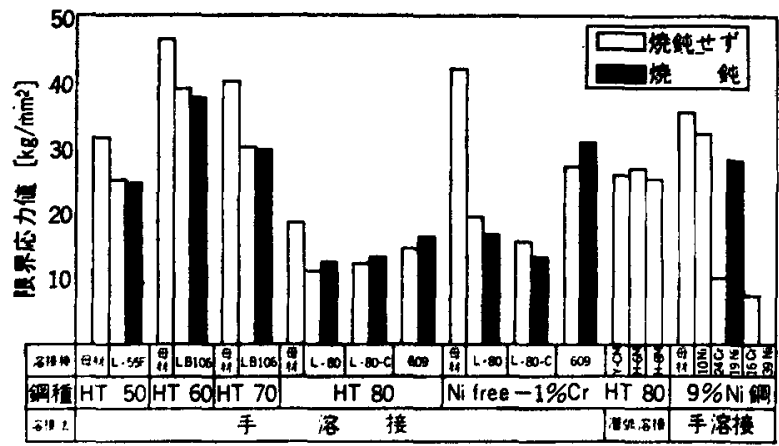

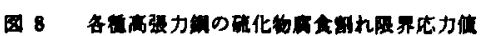

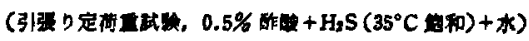

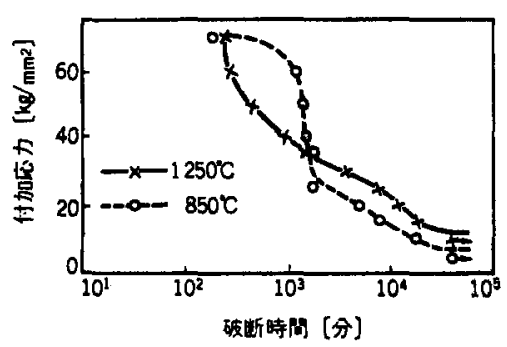

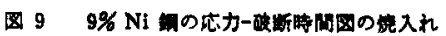

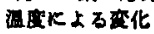

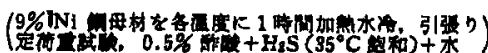


表 1 普通 80 キロ高張力銈および Ni free-1\% Cr 80 キロ高張力鋮溶接継手の破断位冝

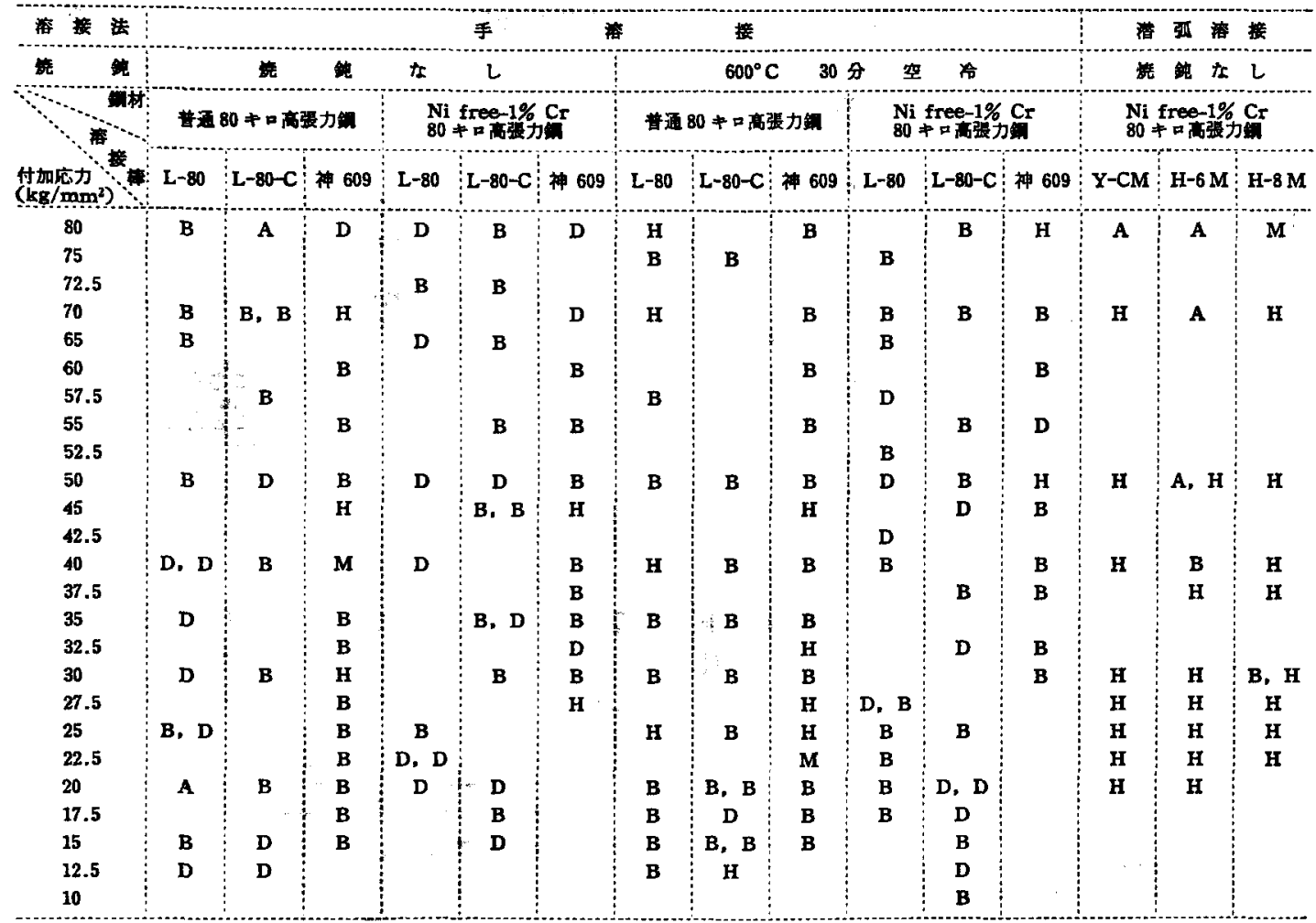

記号の説朚

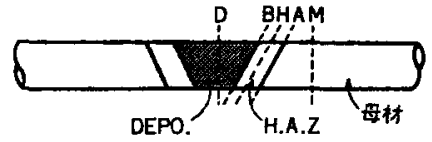

今このよ なな性質をるつニつの蛆織の部分が試険片の 平行部に共存する場合を考えると, $35 \mathrm{~kg} / \mathrm{mm}^{2}$ 以上の応 力值では $1,250^{\circ} \mathrm{C}$ 加熱部で破断し $35 \mathrm{~kg} / \mathrm{mm}^{2}$ 以下の応 力值では $850^{\circ} \mathrm{C}$ 加熱部分で破断することは容易に想像 される。これを溶势熱影䍹部に当てはめてみると加熱温 度に関しては， $1,250^{\circ} \mathrm{C}$ が溶接ボンド部に近い部分にあ たり，850 C が熱影雷部の中央付江にあたる。加熱時間， 冾却速度が上述の熱処理の場合と溶接の場合とでは異な ろので，そのまま同じ結果が溶接の場合に得られるとは いえないか，近い傾向になるるのと推察される。すなわ ち高応力側ではボンド部で，低応力佩ではボンドからは なれた熱影管部で切れる事が予测され，実冓結果とよく 一致する。

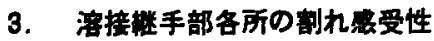

以上述へたよ5に，高張力銅る $9 \% \mathrm{Ni}$ 銅る手溶接継 手に扵るかきり溶接ボンド部付近がきかめて碌いこと

表 $29 \% \mathrm{Ni}$ 銅の手接継手の破断位目

\begin{tabular}{|c|c|c|c|}
\hline 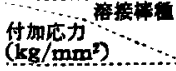 & $10 \% \mathrm{Ni}$ & $24 \mathrm{Cr}-19 \mathrm{Ni}$ & $16 \mathrm{Cr}-39 \mathrm{Ni}$ \\
\hline 70 & A & B & \\
\hline 65 & D & & \\
\hline 60 & $\mathbf{B}$ & B & \\
\hline 55 & D & & \\
\hline 50 & B & B & $\mathbf{B}$ \\
\hline 45 & D & B & \\
\hline 12.5 & A & & B \\
\hline 10 & D & B & B \\
\hline 37.5 & $\mathbf{D}$ & & \\
\hline 35 & $\mathbf{H}$ & $\mathbf{H}$ & \\
\hline 32.5 & & & \\
\hline 30 & & $\mathbf{H}$ & B \\
\hline 25 & & $\mathbf{H}$ & B \\
\hline 22.5 & & H & \\
\hline 20 & & B & B \\
\hline 17.5 & & H & \\
\hline 15 & & & $\mathrm{H}$ \\
\hline 10 & & & $\mathrm{H}$ \\
\hline $\mathbf{5}$ & & & $\mathbf{H}$ \\
\hline
\end{tabular}

㮠曷の䫓明

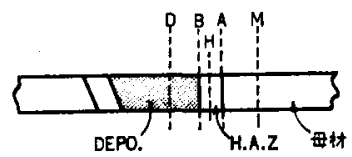


記事特集 食 $\cdot$ 路

があきらかになったが，このことをさらに明膫に表現す るために，図10に示す切久試験片をるちいて，9\% Ni 鋼の溶接熱影䇾部各所の硫化物腐食割れ感受性を求め た。その結果を图 11 に示寸。図 11 で平均応力 $60 \mathrm{~kg} /$ $\mathrm{mm}^{2}$ で試験した三つの曲線をみると，いずれすボンド 部またはその直近の熱影蟹部で破断時間が最す短くなっ ている。3 者のうち 10\% Ni 棒で溶接したるのは他の あのにくらべてこの破断時間の短小はきわめてすくな く、ほとんど減少していないともみられる。

また $24 \% \mathrm{Cr}-21 \% \mathrm{Ni}$ 棒で溶接したものについて平均 応力が $60 \mathrm{~kg} / \mathrm{mm}^{2}$ のものと $40 \mathrm{~kg} / \mathrm{mm}^{2}$ のすのとを比較 すると， $40 \mathrm{~kg} / \mathrm{mm}^{2}$ のるのはポンド部からはなれた熟影 繁部で破断時間がもっとも短くなっている。このこと

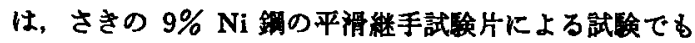
とめた破断位置と応力との興味深い蔺係とよく一致して いる。

図11でさらに興味深いことは，ボンド部からの距崔 が母材側へ 2.5 3.0 mm の付近に破断時間が母材原質 部よりかなり長くなるビーつの存在することである。こ の位㯰はマクロ組織検查でみとめられる熱影䈏部のすぐ

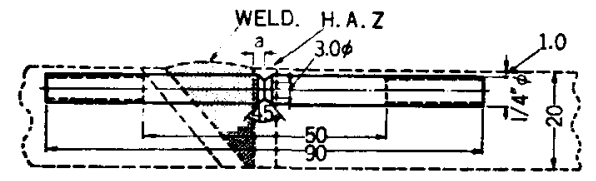

a：ボンドから切久までの㠛 [mm] 切久任半徨 : $0.25 \mathrm{~mm}$

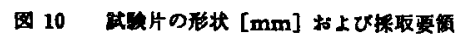

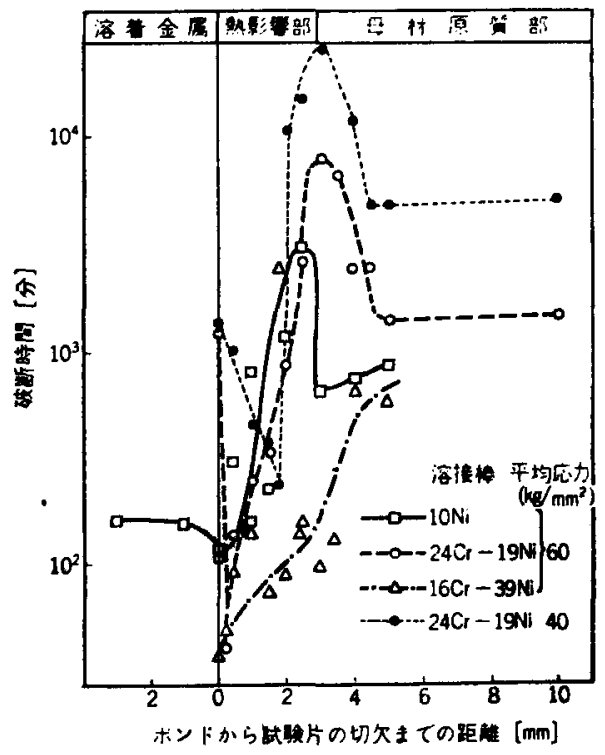

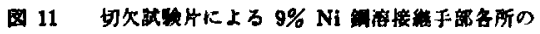

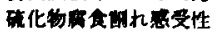

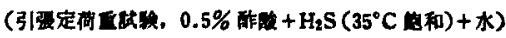

外側にあたり，溶接時に $600^{\circ} \mathrm{C}$ 程度に加熱されたるのと 推定される。9\% Ni 鋼の調質時焼るどし温度は $570^{\circ} \mathrm{C}$ であり，この板を $600^{\circ} \mathrm{C}$ で加熱すると硫化物腐食割れ寿 命がのびるが, この点については次項でくわしくのべる。

\section{4. 再現熱サイクル諴片による熱影霓部 の硫化物府食割れ感受性の検討}

手溶接継手の場合，特にボンド部が硫化物腐食制れに 対して感受性が高くなることが明らかになった。

その原因としては，溶接時に高温にさらされるために 成分元秦の拡散や組織が粗粒化することなどが考えられ る。

ここでは，成分元素の拡散の問題は一応割采して，溶 接熱サイクルによる組織変化が硫化物腐食割れ感受性に およをす効果について検討する。

図12に示した試鈋を用いて，図13中の実線で示し た手溶接鶖サイクル A および B を再現させたすの，お 上び図 14 の実線で示した潜弧溶接熱サイクル B および
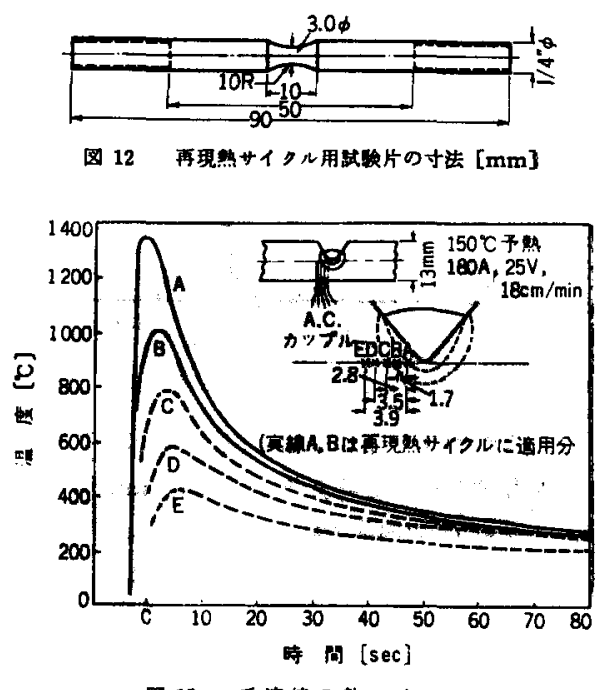

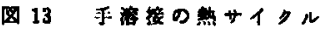

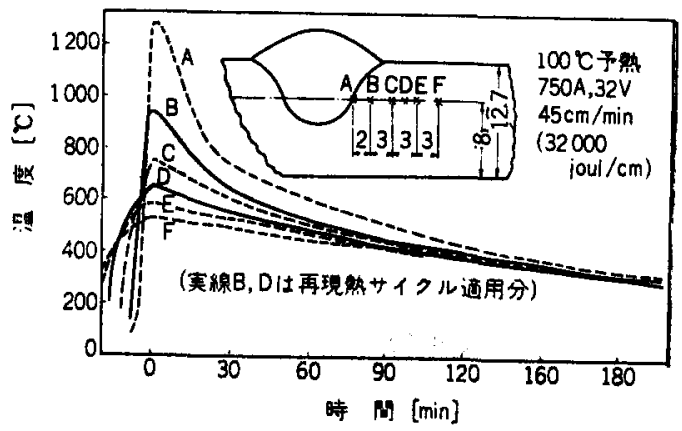

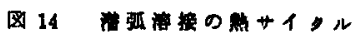


Dを再現させたものについて硫化物腐食割れ試験を行な

い, 応力一破断時問図を求めた。

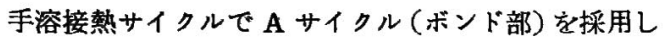
たのは，手溶接継手試験片の硫化物腐食割机破断位置の 多くがボンド部であったので，これを再現させることを ねらいとした。また手溶接の B サイクルを採用したの は，熱影響部のなかほどの部分がボンド部よりどの程度 強いのかを比較検討するためである。

潜弧溶接継手の硫化物腐食割れ烒験に扑ける破断位置 は多くの場合，熱影響部の母材よりであったので，この 位膡に対応寸る熱サイクルとして図14の B サイクルを 採用した。また D サイクルは熱影響部のすぐ外側に当 たる部分で，比較検討のために採用した。

得られた応力一破断時間図を图 15 および図 16 亿示す。

図 15 は，普通 80 キロ高張力鋼打よび Ni free- $1 \% \mathrm{Cr}$ 80キロ高張力鋼に手溶接の場合のボンド部括よび熱影響 部中央付近の溶接熱サイクルを再現させたるのである。 4 本の曲線の 万ち Ni free- $1 \%$ Cr 80 キ口高張力鋼に熱 サイクル B を与えたるの以外は，ほとんど重なった結 果になっている。Ni free-1\% Cr 80 キ口高張力鋼に熱 サイクルBを与えたるのは比較的高応力では破断時間が かなり長くなっているが， しかし破断時間が $3 \times 10^{4}$ 分 になる限界応力値でくらへててるるはとんど差がない。

図 16 は， Ni free- $1 \%$ Cr 80 キ口高張力鋼に潜弧溶接 の場合の熱サイクルを与えたるのであるが，サイクル $\mathbf{B}$ とDの間にはかなりの開きがある。

以上の応力-破断時間曲線から $3 \times 10^{4}$ 分で規定される 限界応力値を求めて図示したのが图 17 である。それぞ れの再現熱サイクルで最高加熱温度も冷却速度も異なる が，今これを最高加熱温度についてみると一定の関係の あることが5かがえる。すなわち最高加熱温度が 1,000 ${ }^{\circ} \mathrm{C}$ 以上の場合には普通 80 キ口高張力鋼， Ni free- $1 \%$ Cr 80 キロ高張力鋼を問わず限界応力值はほほ $12 \mathrm{~kg} /$ $\mathrm{mm}^{2}$ 付近にある。ところが Ni free- $1 \%$ Cr 80 キロ高 張力鋼で最高加熱温度が $950^{\circ} \mathrm{C}$ の場合には限界応力値が $24 \mathrm{~kg} / \mathrm{mm}^{2}$ 付近まで上年し, $650^{\circ} \mathrm{C}$ の場合には限界応力 值が $41 \mathrm{~kg} / \mathrm{mm}^{2}$ と母材の限界応力值と同じ値にまで上 界している。

以上の事からみて, $1,000^{\circ} \mathrm{C}$ 以上の加熱を 5 け急冷さ れると普通 80 キ口高張力鋼す Ni free- $1 \%$ Cr 80 キ口高 張力鋼す同程度に限界応力值が低下して両者の間の差が 消失する。この理由としては普通 80 キロ高張力鋼す $\mathrm{Ni}$ free-1\% Cr 80 キロ高張力鋼るとるに粗粒マルテンサイ トが形成されるため, 両者の硫化物腐食割れ感受性の差 がなくなったるのと考えられる。これが普通 80 キロ高 張力鋼と Ni free- $1 \%$ Cr 80 キ口高張力鋼との限界応力 值に母材としては大きな差がありながら，溶接継手とし

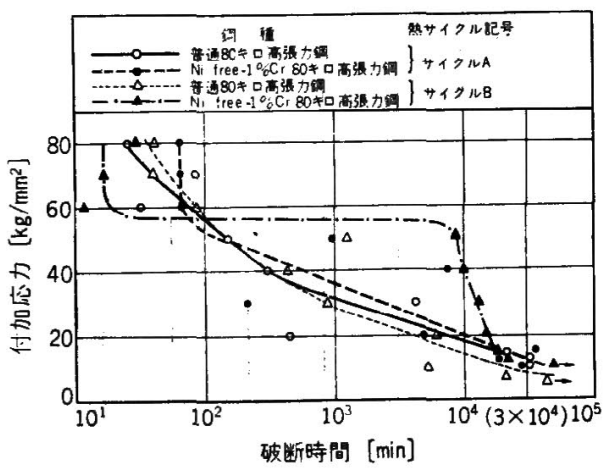

図 15 再現烸サイクルを与えた陚片による硫化物腐食

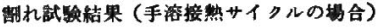

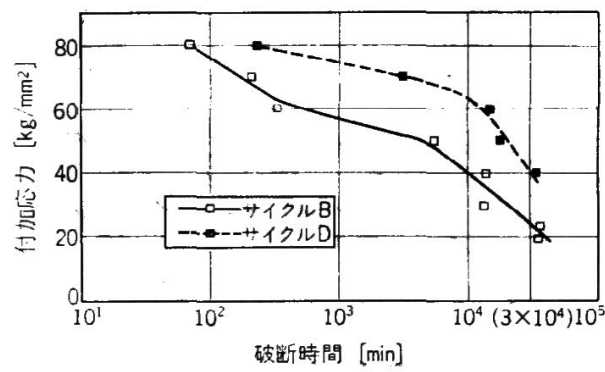

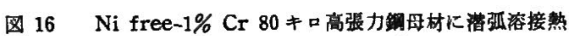
サイクルを与えた場合の応力ー破断時間园

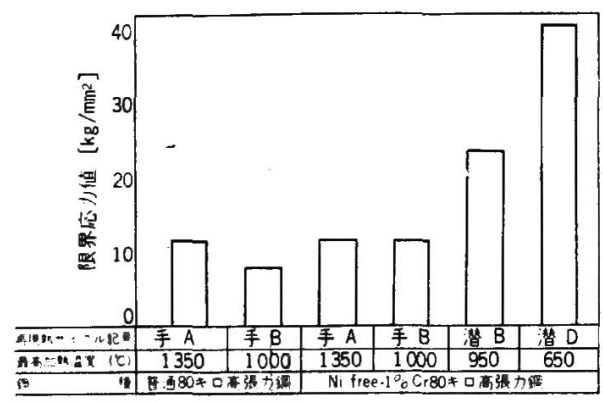

凶 17 再現繁サイクル試片の限界応力值

てはどちらる同程度に劣化する事の原因である。

以上は溶接継手が劣化することを主として再現熱サイ クルの最高加熱温度の観点から検討したが，次に冷却速 度の影裂についてみる。

図 18 は $1,350^{\circ} \mathrm{C}$ から種々の冷却速度の熱サイクルを Ni free-1\% Cr 80 キロ高張力鋼に与えたるのについて 硫化物腐食割れ試験を行なった結果である。図の横軸は $800^{\circ} \mathrm{C}$ から $500^{\circ} \mathrm{C}$ まで朎却するに要する特間をとって ある。この泠却時間が約 50 秒までは冷却時間ととすに 破断時間が急速に長くなる。ところが 50 秒以上の冷却 時間では破断時間はほとんど变化せず一定の值を示す。

この図から見て，硫化物腐食割れに対するボンド部の 劣化を防ぐとは，冷却速度を遅くした方が望をしいよう 


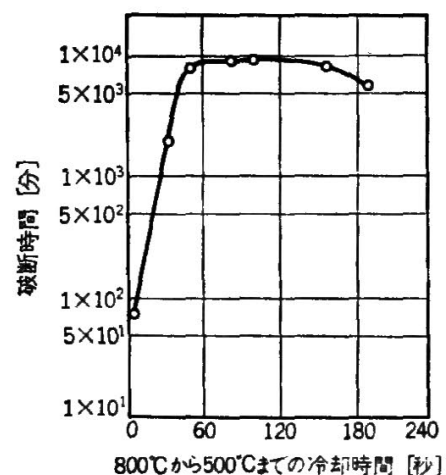

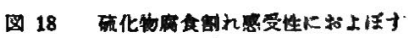
合却速度の影些

$180 \neq$ ×・高登力的

最高加熱沮度 : $1,350^{\circ} \mathrm{C}$

引張り定荷重武原, 庆力: $54.3 \mathrm{~kg} / \mathrm{mm}^{2}$

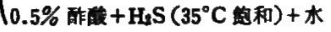

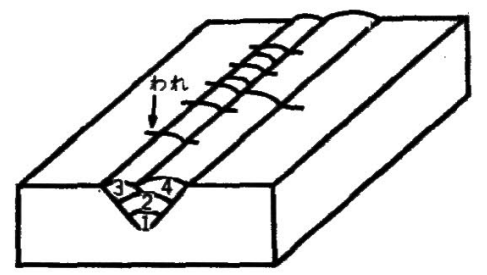

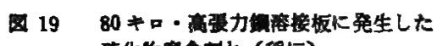
化物零食割れ（程垣）

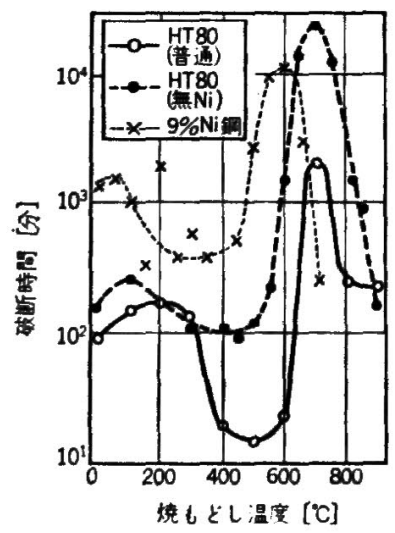

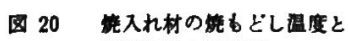
破断時間との関釈

整入れ：1.200号上り HT 80 は办合 $9 \%$ Ni 筑は空菖

榷しどし：1時間, 水命

武聒究力： $54.3 \mathrm{~kg} / \mathrm{mm}^{2}$

に見える。組織的には中間段階組織むたは焼準組織にな っている。

\section{5. 多展溶接の㙁合の硫化物属食割れに 対する一考宾}

80 キロ，高㖘力鋼を图19に示すよ5に溶接して腐食
液中に漫清すると，溶接残留応力によって割れが発生す るが，その発生部位は，因に示すように最終層である 4 パスよりる，その一つ前の 3 パス上である5゙。

4バス恃自己の溶接熱サイクルのみを受けているのに 対し， 3 バスは自己の溶接熱サイクルを受けた後，4パ ス目の溶接によって熱を受けている。その結果，組織上 4パスより3バスの方がより割れやすくなったのではな いかと考えられる。すなわち，多層溶接の場合には，次 の層の溶接によるテンパーの効果も重要な因子として考 えなけれぱならない。

テンパーの効果を知るために，次のような基礎実験を 行なった。すなわち, 普通 80 キロ高張力鋼, Ni free$1 \% \mathrm{Cr} 80$ キ口高張力鋼および $9 \% \mathrm{Ni}$ 鋼を $1,200^{\circ} \mathrm{C} て ゙$ 1 時間加熱して前 2 者は水冷, 後者は空冷をしたものを 基準サンプルとして，これを各温度で 1 時間再加熱して 水冷したすのを一定付加応力 $54.3 \mathrm{~kg} / \mathrm{mm}^{2}$ で硫化物腐 食割れ陚験を行なって破断時間を求めた。その結果を园 20 に示す。

因20で，普通 80 キロ高張力鋼および Ni free-1\% Cr 80 キр高張力鋼は， $150 \sim 200^{\circ} \mathrm{C}$ の再加熱で破断時間は やや長くなる。これは，雄入れ時に発生した内部歪の除 去によるあのと考えられる。これより高い温度で再加熱 すると，破断時間は次第に短くなり，500 $\mathrm{C}$ 付近で最も 短くなる。破断時間がこのように最も短くなる度合い は，普通 80 キロ高張力釗で，はなはだしく，锆入れの ままの破断時間よりはるかに短くなる。

先の 図 19 の溶接板で 3 ハススら多数の割れが発生し たのは 4 パスの溶接により3バスが $400 \sim 600^{\circ} \mathrm{C}$ の加鶖 を受け，3パスの容接のままの場合より，はるか搳れ やすくなったすのと考えられる。

このような温度範囲の再加熱により寿命がきかて短 くなるのは摬すどし脆性に起因するすのと考えられる。

再加熱温度が $600^{\circ} \mathrm{C}$ を越えてさらに高くなると破断時 間は急速に唇くなり，䄪 $700^{\circ} \mathrm{C}$ の点でビークがあらわ れ, $700^{\circ} \mathrm{C}$ 以上の再加熱温度では破断時間は逆㴔激汇 短くなる。

9\% Ni 鋼の場合もはぼ同じような傾向を示すが，そ れぞれのビークや谷のあらわれる温度がやや低温側にず れている。すなわち最初のピークが出る温度は約 $50^{\circ} \mathrm{C}$ であり，谷のあらわれる再加熱温度は $300 \sim 350^{\circ} \mathrm{C}$ であ り，破断時間が最も長くなる第2のピークのあらわれる 温度俚約 $600^{\circ} \mathrm{C}$ である。

ここで注目すべきとと、，第2のビークのあらわれる 再加熱温度と $\mathrm{Ac}_{1}$ 点との関係である。すなわち，普通 80 キロ高張力銈の $\mathrm{Ac}_{1}$ 点は $738^{\circ} \mathrm{C}$ であり $\mathrm{Ni}$ free- $1 \%$

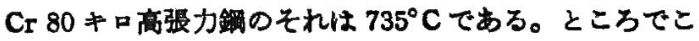
れら再者の第 2 のピークのあらわれる再加熱温度は約 
$700^{\circ} \mathrm{C}$ である。

一方 9\% $\mathrm{Ni}$ 鋼の conventional $\mathrm{Ac}_{1}$ 点は $640^{\circ} \mathrm{C} て ゙$ あり、この場合の第 2 のピークのあらわれる温度は 600 ${ }^{\circ} \mathrm{C}$ である。すなわちこれら三つの材料の $\mathrm{Ac}_{1}$ 点直下の 温度で第2のピークがあらわれるということである。

図 20 の場合は暁入れ材を再加熱した場合の結果であ るが，母材をそのまま加熱した場合の結果としての図 21

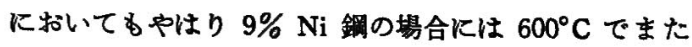
Ni free-1\% Cr 80キロ高張力鋼の場合にはかすかでは あるが $700^{\circ} \mathrm{C}$ 付近に破断時間が最す長くなるピークが認 められる。ところで図 11 に示した溶接継手部各所の硫 化物腐食割れ感受性をみるに熱影響部のすぐ外側に破断 時間が最る長くなるピークがあらわれている。

このピークはち上らど因 21 のピークに対応するるの と考光られる。

\section{6. 石油精製装でのブラントテスト 結果について}

一般に破壊現象は多くの場合実験室試験の結果と実際 の現象とが一致しがたいるのである。特に腐食をともな ろ現象の場合には，そのあまりにす多い影篅因子のため にますますその傾向が強い。

したがって，一方では実験室の加速試検により現象の 諸特性を研究すると同時火他方では実装置内でのプラン トテストにより赛験室テストとの相関性を明らかにして おくことが実用上せひとも必要なことである。

ここではこのよらな意味において，筆者らが石油精製 装置で行なったブラントテスト ${ }^{6)}$ の結果の概要について 述へる。

わが国製鋏 6 社の $50,60,70,80 \mathrm{~kg} / \mathrm{mm}^{2}$ 称高張力 鍴（板厚 $25 \mathrm{~mm}$ ) と棒メーカー4 社のそれぞれの高張力 鋼用の棒を用いて手溶接板を製作した。この溶接板の表 面下 $1 \mathrm{~mm}$ 研削した所から图 22 に示す寸法の試験片を 採取した。母材試片も同じ要領で採取した。

試験片への応力付加は 4 点支持型の曲け治具 (SUS 27 製）によった。

そう入ブラントは石油精製の主要な装置の中で硫化物 腐食割れと関係の深い環境のすのを中心に選んだ。試験 片をそう入したブラント名，ブラントのふん团気，ての 他の条件をまとめて表 るに示す。

試験片のそろ入期間は約 1 年間で，試験片のそう入な らびに開放取り出しはいずれす各現業所の定期開放検査 時に行なった。

ブラントテストで得られた応力と割れとの関係を一括 して表4 亿示す。

母材飞ついては灯軽油水添脱硫装眉ストリッパー 0.

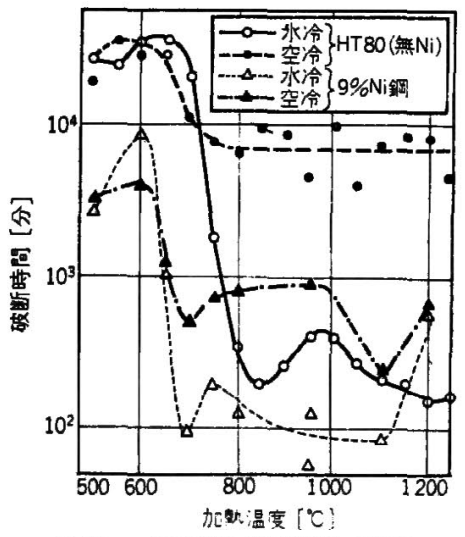

图 21 加䧼温度と破断時间との夙俰 各温度に 1 時間加繁,

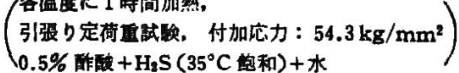
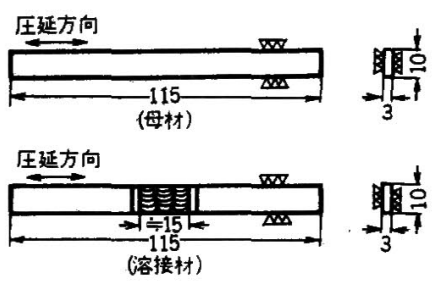

図 22 試強片の形状 [mm]

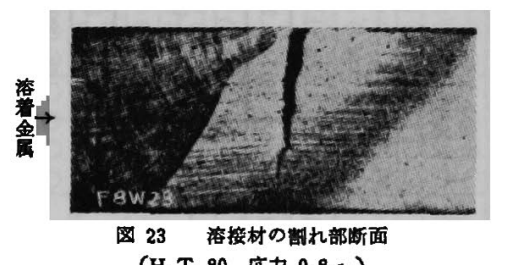

(H. T. 80, 応力 $0.8 \sigma_{y}$ )

H. レシーバー (ブラント番号 1〜4) ならびに常圧蒸留 装置主精留塔リフラックスドラム（プラント番号 4)の みに割れが発生した。

一方，溶接材では割れは母材に比へてかなりはげしく 起こった。特淮水添脱硫装置のストリッパーO.H. レシ ーバー（ブラント番号 1 3，1４）についての結果は注 目される。

また割れのはとんどのものは図23にその一例を示す よろに溶接熱影響部の最高硬度部に現われたが、このこ とは実験室試験の結果とよく一致するといえよう。

表 4 中, 常王蒸留装置 (プラント番号 4 ) については, HT 70 母材にほとんど全数微小割れが出ているが，HT 70 溶接材では全く割れが出ていない。これは一見常識に 反するよ5K思われる。これらの試験片の状態は図 24 に示すように，他のブラントでの割れとはやや变わった 状態を示している。このブラントにそら入した試験片は 


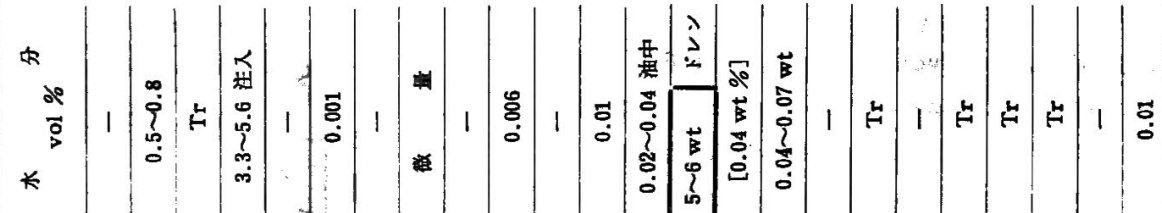

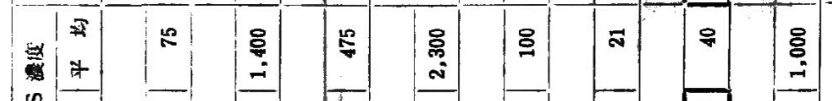

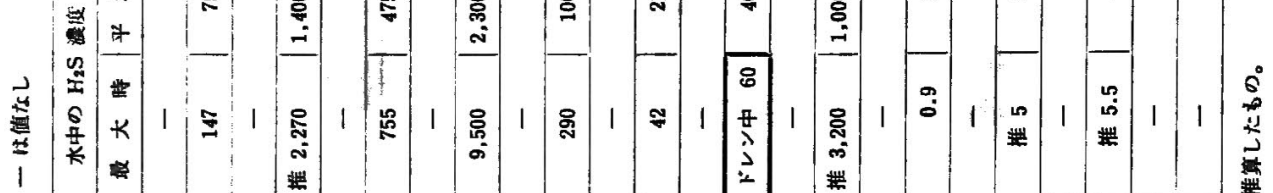
通

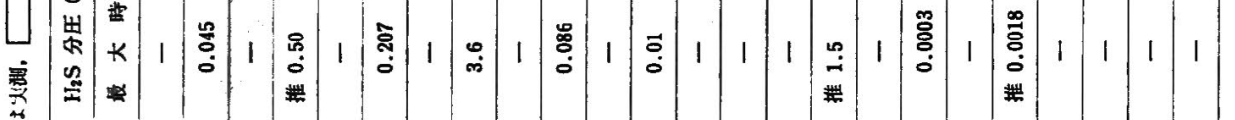

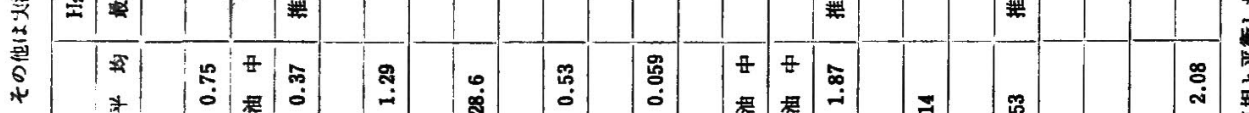

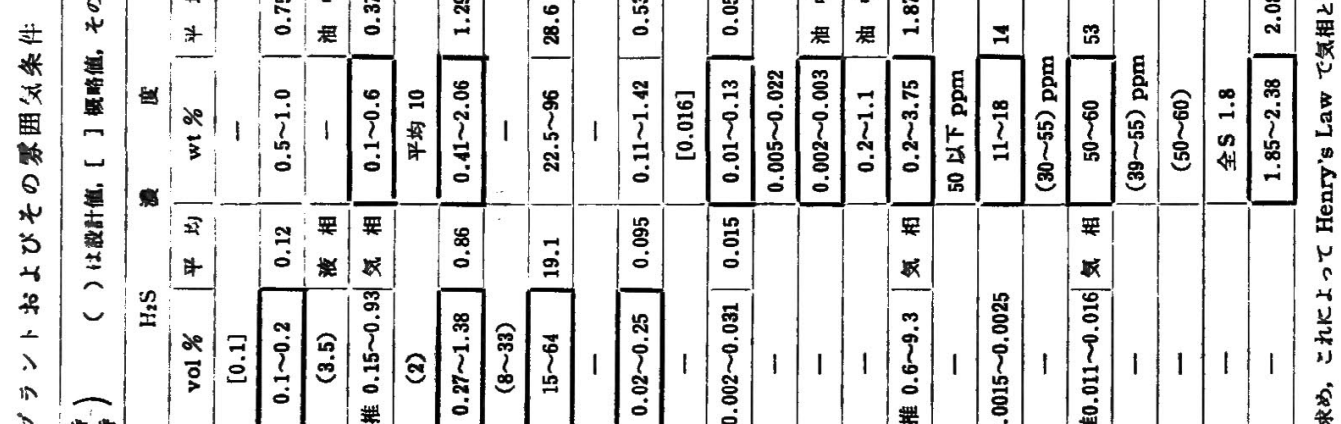

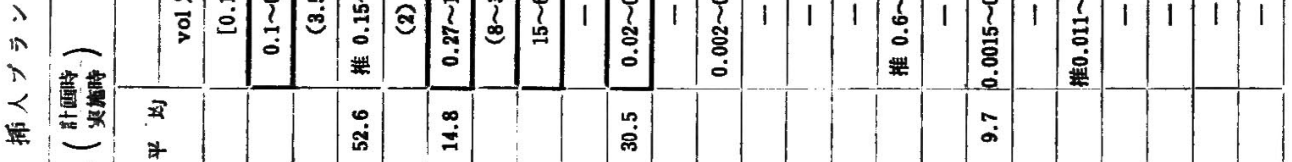

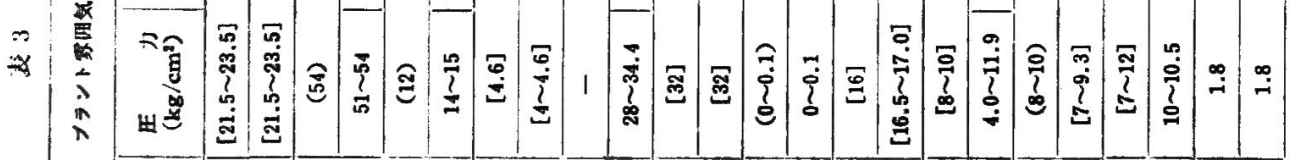

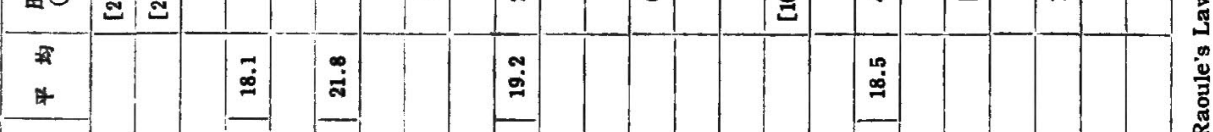

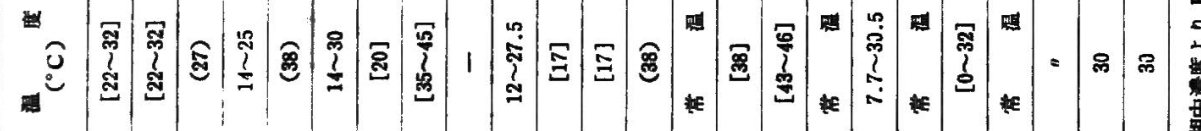

\begin{tabular}{|c|c|c|c|c|c|c|c|c|c|c|c|c|}
\hline 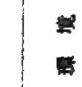 & $\begin{array}{l}\text { 파 } \\
\vec{x}\end{array}$ & 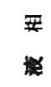 & 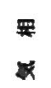 & $\begin{array}{l}\text { 要 } \\
\mathbb{2}\end{array}$ & 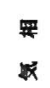 & 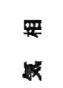 & \$ & $\begin{array}{l}\text { 黑 } \\
\text { 践 }\end{array}$ & 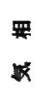 & 舞 & 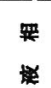 & 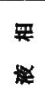 \\
\hline 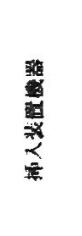 & 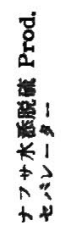 & 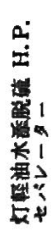 & 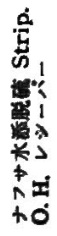 & 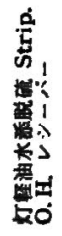 & 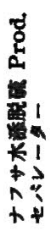 & 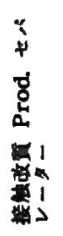 & 凅 & 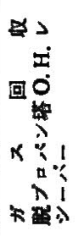 & $\begin{array}{l}i \\
i \\
1 \\
0 \\
0 \\
0 \\
0\end{array}$ & $=$ & $=$ & $\begin{array}{l}a \\
4 \\
4 \\
4\end{array}$ \\
\hline ì & $I$ & $\underline{-}$ & $I$ & $\bar{I}$ & I & N & $\pi$ & in & $\vec{b}$ & t & ? & $\sim$ \\
\hline
\end{tabular}




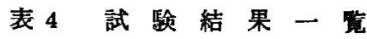

\begin{tabular}{|c|c|c|c|c|c|c|c|c|c|c|c|c|c|}
\hline \multirow{5}{*}{ 㐁 } & $\begin{array}{l}X \sigma_{y} \\
1.0\end{array}$ & $\begin{array}{lll}0 & 0 & 0 \\
0 & 0 & 0 \\
0 & 0 & 0 \\
0 & 0 & 0\end{array}$ & $\begin{array}{lll}0 & 0 & 0 \\
0 & 0 & 0 \\
0 & 0 & 0 \\
0 & 0 & 0\end{array}$ & $\begin{array}{lll}0 & 0 & 0 \\
0 & 0 & 0 \\
0 & 0 & 0 \\
0 & 0 & 0\end{array}$ & $\begin{array}{llll}0 & 0 & 0 \\
0 & 0 & 0 \\
0 & 0 & 0 \\
0 & 0 & 0\end{array}$ & $\left|\begin{array}{lll}0 & 0 & 0 \\
0 & 0 & 0 \\
0 & 0 & 0 \\
0 & 0 & 0\end{array}\right|$ & $\begin{array}{lll}0 & 0 & 0 \\
0 & 0 & 0 \\
0 & 0 & 0 \\
0 & 0 & 0\end{array}$ & $\mid \begin{array}{lll}0 & 0 & 0 \\
0 & 0 & 0 \\
0 & 0 & 0 \\
0 & 0 & 0\end{array}$ & $\begin{array}{lll}0 & 0 & 0 \\
0 & 0 & 0 \\
0 & 0 & 0 \\
0 & 0 & 0\end{array}$ & 10 & c & & b \\
\hline & 0.8 & \begin{tabular}{lll|}
0 & 0 & 0 \\
0 & 0 & 0 \\
0 & 0 & 0 \\
0 & 0 & 0
\end{tabular} & $\begin{array}{lll}0 & 0 & 0 \\
0 & 0 & 0 \\
0 & 0 & 0 \\
0 & 0 & 0\end{array}$ & $\begin{array}{lll}0 & 0 & 0 \\
0 & 0 & 0 \\
0 & 0 & 0 \\
0 & 0 & 0\end{array}$ & $\begin{array}{llll}0 & 0 & 0 \\
0 & 0 & 0 \\
0 & 0 & 0 \\
0 & 0 & 0\end{array}$ & $\left|\begin{array}{lll}0 & 0 & 0 \\
0 & 0 & 0 \\
0 & 0 & 0 \\
0 & 0 & 0\end{array}\right|$ & $\begin{array}{l}0 \\
0 \\
0 \\
0\end{array}$ & $\begin{array}{lll}0 & 0 & 0 \\
0 & 0 & 0 \\
0 & 0 & 0 \\
0 & 0 & 0\end{array}$ & & & & & c \\
\hline & 0.6 & $\begin{array}{lll}0 & 0 & 0 \\
0 & 0 & 0 \\
0 & 0 & 0 \\
0 & 0 & 0\end{array}$ & $\begin{array}{l}0 \\
0 \\
0 \\
0 \\
0\end{array}$ & $\begin{array}{lll}0 & 0 & 0 \\
0 & 0 & 0 \\
0 & 0 & 0 \\
0 & 0 & 0\end{array}$ & $\mid \begin{array}{lll}0 & 0 & 0 \\
0 & 0 & 0 \\
0 & 0 & 0 \\
0 & 0 & 0\end{array}$ & $\begin{array}{lll}0 & 0 & 0 \\
0 & 0 & 0 \\
0 & 0 & 0 \\
0 & 0 & 0\end{array}$ & $\begin{array}{l}50 \\
0 \\
0 \\
0\end{array}$ & $\begin{array}{lll}0 & 0 & 0 \\
0 & 0 & 0 \\
0 & 0 & 0 \\
0 & 0 & 0\end{array}$ & & & & & \\
\hline & 4 & $\mid \begin{array}{lll}0 & 0 & 0 \\
0 & 0 & 0 \\
0 & 0 & 0 \\
0 & 0 & 0\end{array}$ & $\begin{array}{lll}0 & 0 & 0 \\
0 & 0 & 0 \\
0 & 0 & 0 \\
0 & 0 & 0\end{array}$ & $\begin{array}{ll}0 & 0 \\
0 & 0 \\
0 & 0 \\
0 & \end{array}$ & $\mid \begin{array}{lll}0 & 0 & 0 \\
0 & 0 & 0 \\
0 & 0 & 0 \\
0 & 0 & 0\end{array}$ & & $\begin{array}{l}0 \\
0 \\
0 \\
0\end{array}$ & $\begin{array}{lll}0 & 0 & 0 \\
1 & 1 & 0 \\
0 & 0 & 0 \\
0 & 0 & 0\end{array}$ & & & & & \\
\hline & 0.2 & $\begin{array}{ll}0 & 0 \\
0 & 0 \\
0 & 0 \\
0 & 0\end{array}$ & $\begin{array}{lll}0 & 0 & 0 \\
0 & 0 & 0 \\
0 & 0 & 0 \\
0 & 0 & 0 \\
\end{array}$ & $\begin{array}{lll}0 & 0 & 0 \\
0 & 0 & 0 \\
0 & 0 & 0 \\
0 & 0 & 0\end{array}$ & $\begin{array}{lll}0 & 0 & 0 \\
0 & 0 & 0 \\
0 & 0 & 0 \\
0 & 0 & 0\end{array}$ & & & $\begin{array}{lll}0 & 0 & 0 \\
0 & 0 & 0 \\
0 & 0 & 0 \\
0 & 0 & 0\end{array}$ & & & & & \\
\hline \multirow[b]{2}{*}{ 消 } & 1.0 & $\begin{array}{l}0 \\
0 \\
0 \\
0\end{array}$ & & $\begin{array}{lll}1 & 0 & 0 \\
0 & 0 & 0 \\
0 & 0 & 0 \\
0 & 0 & 0 \\
\end{array}$ & & & & & & & & & \\
\hline & 0.8 & $\begin{array}{l}0 \\
0 \\
0 \\
0\end{array}$ & & & & & & & & & & & \\
\hline 技 & & $\begin{array}{ll}0 & 0 \\
0 & 0 \\
0 & 0 \\
0 & 0\end{array}$ & & & & & & & & & & & \\
\hline \multirow[t]{2}{*}{ 材 } & 0.4 & $\begin{array}{l}0 \\
0 \\
0 \\
0\end{array}$ & & & & & & & $\begin{array}{lll}0 & 0 & 0 \\
0 & 0 & 0 \\
0 & 0 & 0 \\
0 & 0 & 0\end{array}$ & & & & \\
\hline & 0.2 & $\begin{array}{lll}0 & 0 & 0 \\
0 & 0 & 0 \\
0 & 0 & 0\end{array}$ & $\begin{array}{lll}0 & 0 & 0 \\
0 & 0 & 0 \\
0 & 0 & 0\end{array}$ & $\begin{array}{ll}0 & 0 \\
0 & 0 \\
0 & 0\end{array}$ & & $\left|\begin{array}{lll}0 & 1 & 0 \\
0 & 0 & 0 \\
0 & 0 & 0 \\
0 & 0 & 0\end{array}\right|$ & $\begin{array}{lll}0 & 0 & 0 \\
0 & 0 & 0 \\
0 & 0 & 0 \\
0 & 0 & 0 \\
\end{array}$ & $\begin{array}{lll}0 & 0 & 0 \\
0 & 0 & 0 \\
0 & 0 & 0 \\
0 & 0 & 0 \\
\end{array}$ & $\begin{array}{lll}0 & 0 & 0 \\
0 & 0 & 0 \\
0 & 0 & 0 \\
0 & 0 & 0 \\
\end{array}$ & & & & c \\
\hline \multicolumn{2}{|c|}{ 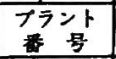 } & 1 & & $1-2$ & & $1-4$ & & & 5 & $6-$ & & $0-3$ & \\
\hline \multicolumn{2}{|c|}{ 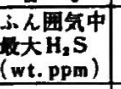 } & . 000 & 000 & & & 960,000 & 1,30 & &, 5 & 18 & & 0 & $2.38 \%$ \\
\hline \multirow{2}{*}{\multicolumn{2}{|c|}{ ブラント名 }} & & & 軖油七 & $+7+0 . \mathrm{H}$. & & \multirow[t]{2}{*}{\begin{tabular}{|l} 
接 \\
改 故
\end{tabular}} & \multirow[t]{2}{*}{$\begin{array}{l}\text { 棠厓 } \\
\text { 渄留 }\end{array}$} & \multirow[t]{2}{*}{$\begin{array}{l}\text { 力 } 2 \\
\text { 回 収 }\end{array}$} & \multirow{2}{*}{\multicolumn{3}{|c|}{ L P Gタンク }} & \multirow{2}{*}{$\begin{array}{l}\text { 原 油 } \\
\text { タンク }\end{array}$} \\
\hline & & & & & & & & & & & & & \\
\hline
\end{tabular}

各得とも上からH.T. 80, H.T.70, H.T.60, H.T.50の㮌

$\bigcirc$
○割れの発生しなかったしの

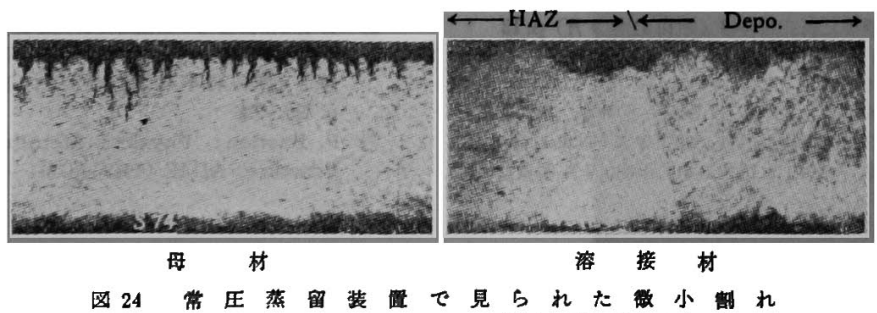

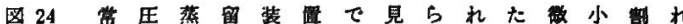

(H. T. 70, 応力 $1.00 y$ ) 

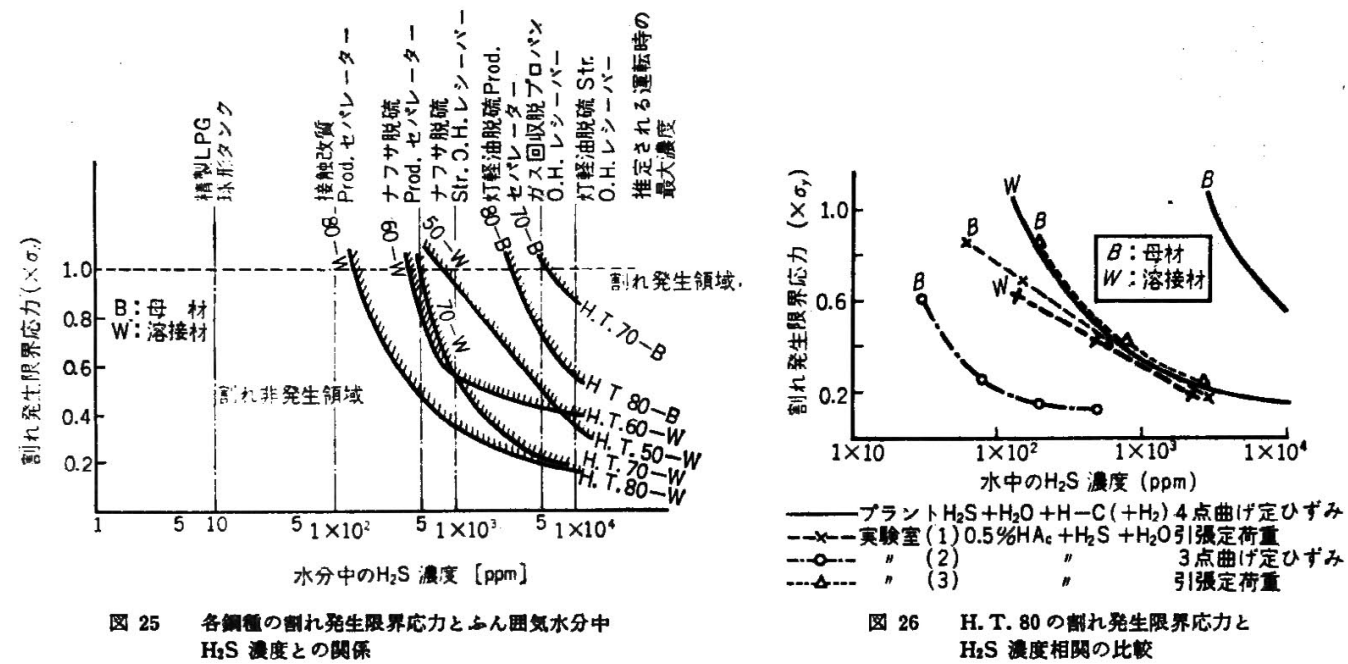

因 26 H.T. 80 の䢂れ発生限果态力と $\mathrm{H}_{2} \mathrm{~S}$ 港度相閶の比

全般に特に腐食がはげしかったことが今一つの特徽であ

ク，割れの特異性とる関保するるのと考光られる。

硫化物腐食割れには，水分が必須の条件であるといわ れている”。そこで、試耠牌そら入したブラント内の 油，ガス中に含まれている水分中に溶解している硫化水 素の濃度を実测または Henry の法則および Raoult の 法則によって推算した。そして，表 4 の結果の割れたる のと割れなかったものとの境界の応力值とこの水分中の 硫化水素浱度との関保を图示すると图 25 のようになる。 因 25 には表 3 の各装置機器の実测最大硫化水素浱度の 2 3割增しを考え推定される運転時の最大濃度線として 引き，各鋼種の危險性との相関を示した。

图 26 はブラントテストの結果（因 25）と実匼室テス トの結果との比較の一例である。母材では両者でかなり の隔たりがあるが，溶接材の場合には四材にくらでてか， なり近ついている。特に, 硫化水素の飽和漬度 (常温) の付近ではよい一致を示している。

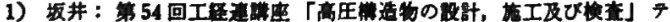
十ス卜(昭和 38 年 3 月)

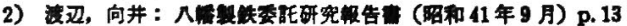

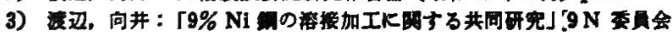
(昭和 41 年 8 月) p. 319

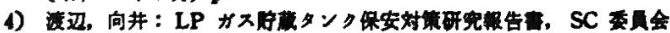

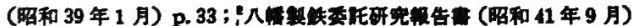

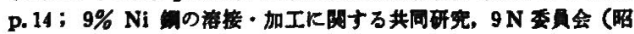
和 41 年 8 月) p. 320

\section{結 官}

硫化物腐食割れに対する関心は石油精製装置やその他 の化学機器に関係する部門を中心にして最近ますます高 くなり，その諸特性は次第に明らかにされてきた。

しかし硫化物腐食割れの発生機構に関しては全く不明 のままで残されているし，また実際面での防止策として も満足なものはない。

筆者（渡辺）が発案した Ni free-1\% Cr $80 \neq$ キ高張 力銅はたしかに防止策としては糟極的な方向に向からも のであるが,これとても溶接ボンド部にまだまだ問題を 残しているようである。

今後一方では硫化物腐食割れの発生機構の解明のため の学究的な研究が進められると同時に完全な防止対策の 開発に力が注がれることが望まれる。

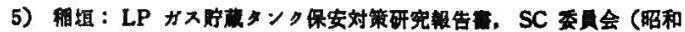
39 年 1 月) p. 48

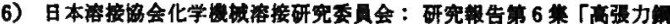

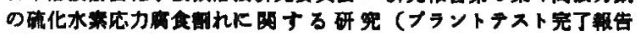

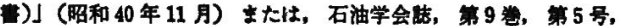
p. $393 \sim 398$

7) P. Bastien: Phyoical Metallirgy of Strese Corrosion Fracture, AIME (1959) p. $311 \sim 340$

[特集終わり] 